\title{
HISTORY OF VETERINARY MEDICINE AMONG ARABS BEFORE ISLAM
}

\author{
Hadeel Ghaleb Abbas \\ Department of History, Faculty of Education Ibn Rushed for Humanity, University of Baghdad
}

DOI: $10.37648 / \mathrm{ij} r s s h . v 10 \mathrm{i} 01.003$

Received: $06^{\text {th }}$ September, 2019; Accepted: 08th October, 2019; Published: $29^{\text {th }}$ October, 2019

\begin{abstract}
The animal was the mainstay of the life of the first Arab. Their country has desert, pastoralism, trade, and the sale of animals. This is the mainstay of their lives, from food to milk and meat, from tents to clothing, and from there to war to protect the tribe and sport them with horses, camels and so on. The Arabs have long cared for the diseases of horses and mules especially in the armies because these animals are important in wars, they wrote about the types of diseases that affect horses and camels and their treatments. Moreover, the interests of veterinary medicine included all animals, ranging from pets from cats, dogs and birds to different horses and camel, they wrote the most beautiful poetry and controlled the finest literary writings.
\end{abstract}

\section{IMPORTANCE OF ANIMALS IN ARABS BEFORE ISLAM}

The animal is an important asset especially for those poor countries that do not have an industry, whose natural resources are limited, and compensate for industry by animal husbandry and agriculture if water is available. The camels in particular are a source of great wealth in the Arab's before Islam, for their benefit in many matters, and the number of camels measured by wealth, camel money in the Arabs, and the basis of dealing between them, which are their capital $\left({ }^{1}\right)$.

$\left.{ }^{1}\right)$ Jawad Ali, the detailed in the history of Arabs before Islam, the fourth edition, 1422 AH / 2001 AD, Dar alSaqi, 13/112, Mohammed Bayoumi Mehran, Studies in the history of ancient Arabs, the second edition, Dar alMaarefah University, p. 113
Among the animals of the Arab countries that have a great place to have horses, which is more than just an animal of ownership and trade, it has a large share and no doubt in the invasion and breeding in the Arabian Peninsula as a reason for the expansion of the invasion and war, and thanks to horses appeared heroes Knights, In the news of the days, the horse is like a hero, must be counted heroes of the battles of those days.

The horse has been the place of pride and interest Arabs, and the source of their love, and continued to honor them, and celebrate them from things that are not hidden to those who read their news and the words of Safi al-Din al hale:

If the people pride themselves in their glory days, then you are one of their people. Glory is glory. The body of 
the little saffron is returning to the same level as the saddle and the cradle $\left(^{2}\right)$.

The sheep at the urban and the like, raise them to take advantage of their meat and milk and wool, a source of wealth for their owners $\left({ }^{3}\right)$.

The people of the cities and the people of the countryside have been concerned with raising birds, especially chickens, and counting the food of the rich and able to raise the price for the poor, and they used to cook in cooking, and the geese at the Arabs and ducks, young and old, and prepare it from the bird of water.

Farmers and farmers are encouraged to make use of the agricultural services and their pensions, such as camels for transport, tillage, raising water from deep wells, cows to use their milk and meat, plowing and raising water, sheep, goats, chickens and other domestic animals such as ducks, geese $\left({ }^{4}\right)$.

The Arabs, before Islam, took special care of the falcons, who were brought up by special education. The linguists mentioned that everything is caught from the beasts, hawkers and falcons. They used the fast-running dogs in hunting as well, and they raised smart, quickrunning species to chase the prey. The fisherman comes and takes them from her $\left({ }^{5}\right)$.

The ancient Arab interest in the animal is of great interest even in its literature and poetry. The world of ancient poets is crowded with animals. Many animals are mentioned in their poems, and there are lengthy

${ }^{2}$ )MohammedBayoumi Mehran, Studies in the history of ancient Arabs, the second edition, Dar al-Maarefah University, p. 113

$\left.{ }^{3}\right)$ Jawad Ali, detailed in the history of the Arabs before Islam, 13/117

$\left.{ }^{4}\right)$ Jawad Ali, detailed in the history of the Arabs before Islam, 13/117

$\left.{ }^{5}\right)$ Mohammed bin Mohammed bin Abdul Razzaq alHusseini, Abu al-Fayadh, alias al-Zubaidi, the crown of the bride Jawahar dictionary, the investigation of a group of investigators, the House of guidance, 12/341 Saqr descriptions of camels, horses, humpers, birds and snakes. The veteran $\left({ }^{6}\right)$.

The description of Tarfa ibn al-'Abd with his association with 30 houses revealed a fascination with animals, in which he said:

And a skull like high place as if ... and aware of the forum to a cooled letter

The most beautiful cothering of the whole ... as a rock in a tinplate $\left(^{7}\right)$

It is clear that he noticed some things from medicine and veterinary medicine, not just a passing observation, but a rational and conscious observation, namely medical science and veterinary paste. He likened the camel's skull to the anvil, and realized that it was composed of bones.

Serrated, interlocked, holding each other. He also described the heart as a full-fledged, hand-filled man, as hard as a stone, wrapped in a handkerchief, with a pulse and movement $\left({ }^{8}\right)$.

The wonderful animals are seen as valuable gifts that guide kings, along with jewels and antiques, and there is a very rich literature that treats animals as a wonder of the world, and as examples of the wisdom that man learns from them.

The Arabs ate the blood of the animal, dried it after mixing it with another substance, or put it in the intestines to dry and eat, or with the hair and then eat it, and some of them drank blood, to the force. In the hadeeth of 'Akramah, it was the food of the Arabs before the Islam of Al-Atz $\left({ }^{9}\right)$. Which is a food of blood

$\left.{ }^{6}\right)$ Jawad Ali, detailed in the history of the Arabs before Islam, 8/268

$\left.{ }^{7}\right)$ Hussain bin Ahmed bin Hussein al-Zuzani, Abu Abdullah, Explanation of the seven pendants, first edition 1423 - 2002, House of Revival of the Arab heritage, p. 102, Georgy Zidane, the history of Muslim civilization, Cairo, 1958, 3/12-15.

$\left.{ }^{8}\right)$ Tawfiq Pro, The History of the Ancient Arabs, Second Edition, 1422 AH / 2001 AD, Dar al-Fikr, p. 278

${ }^{9}$ )Abu al-Hasan Nur al-Din Ali ibn Abi Bakr ibn Sulayman al-Haythami, resources thirsty to Zuawa'id 
and lint, so that the blood is mixed with litter, or wool spreads and drinks with blood and grilled and eaten, and attributed to the poor and the days of famine, and attributed to the Qahtani,

And the villages of Qahtan in disaster and crisis ... there is no worse of this act and try protect yourself from like act $\left({ }^{10}\right)$.

It is one of the poetry emitted by emotion and no doubt $\left({ }^{11}\right)$.

The Arabs before Islam in their heritage irrigated the hair of camels and horses and the rest of the animals of their environment, and extended talk in them, when talking about camels talked about the strike and carry them and their output and milk and milk and colors and slaughter and proportions and sounds and grazing and drinking and types of walking, and that they have detailed horses and horses in which no one.

As was the isolation of the Arabs before Islam and after the civilized world at the time, it earned them the length of control of their animals that live with them, and those that catch them or kill them and their animals, knowledge of their nature, and printed in their minds characteristics and attributes, and they described them in accordance with this pattern praise or blame, Their names on their children and their tribes; where it was the meaning of power and loyalty, and quoted from the names of these animals like their currents and their likenesses.

The Arabs were interested in animals that they called their sons to some animals, says Al-Jahiz: "The Arabs were called a dog, donkey, stone, and made, and hawk, and monkey, so optimistic. He heard a man say a stone, or saw a stone, called his son by him, and in him the intensity of the hardness, the hardness, the patience and the survival, and he destroyed what was left. And if he heard a man say a wolf or see a wolf, and deceit and

ibn Habban, the investigation of Hussein Salim Asad al-Darrani - Abdo Ali al-Koshak, the first edition, (1411 - 1412 e $)=(1990$ AD - 1992), House of Arab Culture Damascus, 5/430.

${ }^{10}$ )Taj al arwos,243/ 15, Alealhz,

${ }^{11}$ )Al fasil in the history of the Arabs before Islam, $16 / 27$ gain. Even if it is a donkey in which longevity, rudeness, strength and flogging prevail. Even if he is a dog to take care of, guardianship, sound and gain, and so on. "Other opinions on these names and their opinions were included in them $\left({ }^{12}\right)$.

The names of animals that are called by Arabs in Arabs before Islam: crow, and expelled, and Faktha, dove, Yamam, and Yamama, punishment, Katame, partridge, hawk, falcon, peacock, and Tuwais, and Hiktan, and Gharenik $\left({ }^{13}\right)$. The care of the Arabs with animals is what led many writers, writers, authors and historians to put special books in them $\left({ }^{14}\right)$. They have written general books in animals such as the Animal Book of the Al-Jahiz $\left({ }^{15}\right)$ and the Animal Life To Al-Demeary $\left({ }^{16}\right)$.

There is a science in which the Arabs have never encountered one, and they have not competed with one another, such as the book "Horse Breeds," such as the book "Horse Breeds in the Arabs before Islam and Islam, by Hisham Ibn Muhammad Ibn al-Saa'ib alKalbi. Many books dealing with horses in detail in terms of their names. The horses of books that are difficult to enumerate and that deal with horses from near or far, and reached the interest of Arabs animals. They wrote on parts of the body of the animal such as the book and the saddle book and saddle Labi Ubaida Muammar bin Muthanna, did not stop the attention of the ancient Arab horses, but the rest of the animals that the Arabs wrote about her life like: Book of camels and

\footnotetext{
$\left.{ }^{12}\right)$ Amr ibn Bahr ibn Mahbub al-Kinani loyalty, AlLeithi, Abu Othman, famous animal, I 21424 e, scientific bookstore - Beirut, 1/214

${ }^{13}$ ) Al-Jahiz, Animal, 7/53

$\left.{ }^{14}\right)$ Detailed in the history of the Arabs before Islam, $16 / 52$

${ }^{15}$ ) Ismail bin Mohammed Amin bin Mir Saleem alBabani al-Baghdadi, the gift of those who know the names of authors and the effects of works, House of Revival of Arab Heritage Beirut - Lebanon, 1 /614

$\left.{ }^{16}\right)$ Mustapha bin Abdullah, writer of the Chalabi of Constantinople, famous as Haji Khalifa or Haj Khalifa, revealed suspicions about the names of books and arts, Muthanna Library - Baghdad, 1941, 2/1740
} 
the book of nomads and the book of Bazi and the book of pigeons $\left({ }^{17}\right)$.

\section{VETERINARY IN TERM OF MEDICINE AND LANGUAGE}

Medicine in the language: the deletion of something and skill in it $\left({ }^{18}\right)$, either medicine terminology medicine is a science looking at the body of human or animal in terms of health and not $\left({ }^{19}\right)$, the owner tries to maintain health and cure of diseases with medicines and food after the disease is detected that affects every member of the body (human or animal) and the reasons we are obsessed $\left({ }^{20}\right)$ with it Medicine is a science required at all times and places, because it is related to human life, and the Arabs before Islam had knowledge of the medicine in general. Although they often relied on spells, sophistication, determination and expulsion of the Demons from the patient's body, or in a brief word on sorcery and magic, the owners of language from the metaphor: Medicine in the sense of magic, said Ibn al-Aslat:

Not from the amount of Hassan about me ... I was a dawak or madness $\left({ }^{21}\right)$

They found that medicine and magic were connected. It is an expression of the healing of diseases in the past by witchcraft. The magician was a doctor, healed the disease and healed the patient with his magic, and the

${ }^{17}$ )Shahabuddeen Abu Abdullah Yacout bin Abdullah Al RoumiHamwi, Dictionary of Literary Criticism, Ihsan Abbas, First Edition, 1414 AH - 1993, Dar Al Gharb Al Islami, Beirut, 6/2708

${ }^{18}$ ) Abu Hassan Ahmed Ibn Fares, Dictionary of the Language Scale, Investigation of Abdel Salam Mohammed Haroun, C3, Dar Al Fikr (Beirut - Lat), p. 407

${ }^{19}$ ) Ibn ManzoorLassan, The Arabs, 1, p. 554.

${ }^{20}$ ) Abu Ali al-Hussein bin Ali IbnSina, Law in Medicine, Muthanna Library (Baghdad - No. T.), c 1, p. 3.

${ }^{21}$ )Al-Baghdadi, Abdul Qadir Bin Omar, The Book of Literature and the Heart of the Sanab al-'Arab, The Investigation and Explanation of Abdulsalam Muhammad Harun, Fourth Edition, 1418H - 1997, AlKhanji Library, Cairo, 9/295. priests also manipulated the sick, and people still believed in the magic of healing the disease. $\left({ }^{22}\right)$

They also relied on experience. They knew how to cure weeds, and they used amputation to cure corrupt organs in the body, ironing, cupping, eye care, and so on.

At that time, medicine was an honor, and the doctor had a great place among the Arabs before Islam. It was about Zuhair Bin Janab, the master of his people, and their honorable, and their fiancé, and their poet, and their arrival to the kings and their doctor. $\left({ }^{23}\right)$

It was mentioned to the name of Nefir of the doctors, namely: Harith bin Kulda al-Thaqafi, who is from Thaqif and from the people of Taif. He mentioned that he traveled to the country and learned medicine in Persia on a man from the people of Jassab Yasabur, Abu Ramtha al-Tamimi "and" bandage ", all of whom lived the Prophet peace be upon him and realized his time $\left({ }^{24}\right)$, and thanks to this contemporary, their names mentioned in the books of modern and walk and news, and otherwise it would be like others who did not reach their name to one,

It must be sorcerers, sorcerers and priests at the time, who practiced medicine, and treated patients, magic and adoration, or medicines taken by their predecessors and their own experiences $\left({ }^{25}\right)$.

\section{VETERINARY SCIENCE}

Language: The thing that he slows down slowly, he is petty and bad: Apartment, and the stomach: the

${ }^{22}$ ))EmadEddin Ismail Abu al-Fidaa (v. $732 \mathrm{AH} / 1331$

$\mathrm{CE})$, the abbreviated in the news of humans, $(\mathrm{L}-\mathrm{no} . \mathrm{V})$, c 1, p. 128.

${ }^{23}$ ) Ahmed bin al-Qasim bin Khalifa bin Younis alKhazrajiMuwafaq al-Din, Abu al-Abbas Ibn Abi Jibatah, the eyes of the news in the layers of doctors, the investigation of Dr. Nizar Reza, Library of Life - Beirut, p. 161

${ }^{24}$ ) Abu DaoudSulaiman bin Hassan Andalusian MahrouflbnJalhal, layers of doctors and wise men, I Beirut, Foundation letter, 1405 H / 1985, p. 54

${ }^{25}$ ) Detailed in the history of the Arabs before Islam, $16 / 16$. 
incision, and it called Bitar: the animal handler, which is the toys of animals, which treats them, and treatment: Veterinary. $\left({ }^{26}\right)$

He is also said to have a shower. Al-Nabaghah said:

Doubts of the veterinarian and implemented the doubt of the wounds as heals the $\operatorname{arm}\left({ }^{27}\right)$

And Baiter: Bitar the bird, her husband, Samar in her hoof Hodeidah.

And control: it costs the veterinary

Bitar: A veterinarian (veterinarian) ${ }^{28}$ or veterinarians (group of veterinarian) is brought together. ${ }^{29}$ )

And the term: science that examines the conditions of animals in cases of health and disease, has been used the term veterinary and then to date for science, which examines the conditions of animals in general in terms of protection against diseases and treatment, which is like medicine in humans $\left({ }^{30}\right)$.

\footnotetext{
${ }^{26}$ ) Ibn Manzoor, San'a Al Arab, Dar Sader, Beirut, Article (Petr), 4 / 69-70.

$\left.{ }^{27}\right)$ Abu Al-Hussein Ahmed bin Fares bin Zakaria, dictionary of the standards of language, the investigation of Abdul Salam Mohammed Harun, published by the Union of Arab Writers, I in 1423 e / 2002. , P. 247, Nashwan bin Said Al-Hameiri Yemeni, Shams science and medicine Kalam Arabs of Klum, investigation: d. Hussein bin Abdullah Al-Omari Mutahar bin Ali Al-Iryani - d. Yousef Mohamed Abdullah, First Edition, 1420 - 1999, Contemporary Thought House (Beirut - Lebanon), Dar Al Fikr (Damascus - Syria), p. 562. The aortic disease takes in the humerus.

${ }^{28}$ ) Reinhart Peter Ann Dozzi, supplement of Arabic dictionaries, transferred to Arabic and commented by Mohammed Salim Al-Naimi, Jamal Al-Khayat, published by the Ministry of Culture and Information, Republic of Iraq, first edition, 1979-2000, 1/367.

$\left.{ }^{29}\right)$ Ibrahim Mustafa Ahmed Al-Zayat Hamid Abdul Qader Mohammed Al-Najjar, the dictionary of the mediator, the realization of the Arabic language complex, published Dar al-Dawa, 1/79.

${ }^{30}$ ) Abu al-Tayyib Muhammad Siddiq Khan bin Hassan

bin Ali IbnLutif Allah Husseini al-Bukhari al-Qunuji,
}

\section{Veterans of the Arabs}

The Arabs before Islam had great interest in the animal, and did not stop their position on the acquisition or trade or even use it in the means of transportation, and reached a great deal of them, and has reached the animal and health and treatment of diseases a large amount, they lost their animals from diseases and diagnosed and developed the disease treatment, And the specialty of the ignorant of the ignorant of the treatment of animals, they are veterinarians, treat their diseases and prescribe medicines, is said to one of them: the bird and the diet and the breakfast, and the Arabs have not so in their (poetry).

The veterinarian should be an expert on the causes of animals, knowing what they need, and what is going on with them. People will return to him if they differ in the defect of the animal $\left({ }^{31}\right)$.

The term Veterinary, which is used in European languages in a veterinary sense, is believed to be an Arabic word of origin, derived from the word vitar, which became Vitar, and from which the term veterinary was derived. Some researchers argue that the word "Bitar", of Greek origin, is Ippiyatros. $\left({ }^{32}\right)$

\section{Diseases treated by Arabs:}

In the books of literature, the Arab heritage, the dictionaries and the books of the veterinarian, there are a large number of diseases that afflict the animals,

Abjad al-Uloom, first edition 1423 H-2002, Dar Ibn Hazm, p. 314.

$\left.{ }^{31}\right)$ Muhammad ibn Muhammad ibn Ahmad ibn Abi Zayd ibn al-Akhwa, al-Qurashi, Ziyya al-Din, al-Qurba in the request of al-Hesba, Dar al-Funun, p. 152, Abd alRahman ibn Nasr ibn Abdullah, Abu al-Najeeb, Jalal alDin al-'Adawi al-Shizari al-Shafi'iln the request of the honorable Hesba, I press the Committee of authorship, translation and publication, p. 82

34) Abu Bakr Mohammed bin Hassan bin Duraid, derivation, investigation Abdul Salam Mohammed Harun, third edition, the library of the Khanji, Cairo, p. 49

${ }^{32}$ ) Detailed in the history of the Arabs before Islam, 16 / 50-52 
including what the Arabs succeeded at the time in finding a cure and mentioning much that cannot be cured $\left({ }^{33}\right)$. They treated the wounds that afflicted them, and among them were treated with ironing and treatment using tar, and the hero of the patient. $\left({ }^{34}\right)$

* Al-Hazal: It is one of the diseases that the Arabs have infected, which affects the camels and the shia if they eat more than eat the melon, which is a change in the color of her skin and swelling in her breast, and this leads to the corruption of her milk. $\left({ }^{35}\right)$

* The reddish disease: which is a foul smells emitted from the mouths of the dead animals if you eat more than barley Vntn mouths and weight in walking and chest pain, and the members and bulge, said Amro Qais:

To my son Saad bin al-Nafb if tomorrow .......... love us from you Vafrs red

* Taste it with steam $\left({ }^{36}\right)$. And treatment: Fist the hands of the hoof of the following hair, and rose, camphor, violet and chamomile. $\left({ }^{37}\right)$

* Discord: a disease that affects the animals and the flag of the movement of the head and the lack of eating and runny nose, and then shows

${ }^{33}$ ) Ahmed bin Ali bin Ahmed Al-Fazari Al-Qalqashandi, Sobh Al-A'shi, in the construction industry, the Scientific Book House, Beirut, 2/30.

${ }^{34}$ ) Abu Bakr Mohammed bin Hassan bin Duraid, derivation, investigation Abdul Salam Mohammed Harun, third edition, the library of the Khanji, Cairo, p. 498.

${ }^{35}$ ) Tage al arwos Jewels Dictionary, 28/3.

${ }^{36}$ ) ) Abu Nasr Ismail bin Hammad Al-Jawhari Al-Farabi, Al-Sahah Language Taj and Saheeh Al-Arabiya, Investigation Ahmed Abdul Ghafoor Attar, Fourth Edition $1407 \mathrm{H}-1987$, Dar Al-Ilm for millions - Beirut, 2/638, Ahmad Bin Fares Bin Zakaria Al-Qazwaini AlRazi, Study and Investigation of Zuhair Abdul Mohsen Sultan, Second Edition 1406 H - 1986, Al - Resalah Foundation, Beirut, 1/250.

${ }^{37}$ ) Mohammed bin Abdul QadirAljazairy, elite contract of horses in the Saphnat horses, p. 70. a rectangular view behind the ear, and treatment: flaxseed and flour with soap $\left({ }^{38}\right)$.

* Crash: a disease that affects the animal in its lists or weakness. And cause wasting and severe weakness of the animals. $\left.{ }^{39}\right)$

* Mughal: the pain that afflicts the animals in their stomachs as a result of eating the soil with the weight, or: eating the chicken droppings, and benefiting the spoiler the possibility of wicks from the hennett and hawthorn, and blowing some of the pepper in the male urethra and releasing the female in the pipe, watering the water of the ring. $\left({ }^{40}\right)$

* Al mashash: a disease that affects animals. Some white camels in her eyes and swell until her eyelids cling. $\left({ }^{41}\right)$

* Al qaser: The disease of the horse if the sweat, and lifted the saddle or touched the cold, which is a congestion, and the difference between them that it is in the back and neck, and short in the absolute nerves, and treatment: the impact in a hot place reserved from the air, and incense and blackness and canard, the roses, if the lacquer is not cleared in the neck, head and the origin of the sin. $\left({ }^{42}\right)$

It is a disease that affects the animals of the Arab is a blisters (boils) in the body of the animal called scabies,

${ }^{38}$ ) Dr. Ibrahim Anis, Dar Al-Shaab Foundation for Press, Printing and Publishing, Cairo. , 1424 H - 2003 AD, $3 / 86$.

${ }^{39}$ ) Abu Al-Hussein Ahmed bin Fares bin Zakaria, Dictionary of the Standards of Language, the investigation of Abdul Salam Mohammed Harun, the first edition 1399 - 1979, Dar al-Fikr, 2/78.

${ }^{40}$ ) Abu Bakr Mohammed bin Hassan bin Durid al-Azdi, the mass of language, a symbolic investigation MounirBaalbaki, the first edition, 1987, Dar al-Ilm for millions - Beirut, 2/960.

${ }^{41}$ )Mohammed bin Mohammed bin Abdul Razzaq alHusseini Abu al-Fayadh, alias al-Zubaidi, crown of the bride Jawahar dictionary, 17/385, Abu Hassan Ali bin Ismail bin SidhiMursi, the arbitrator and the Great Ocean, 1/368.

${ }^{42}$ ) Nashwan bin Said al-Humeiri, Shams al-Uloom and the medicine of the words of the Arabs from the Kuloum, 6/3328, Abu Ibrahim Ishaq ibn Ibrahim ibn alHussein al-Farabi, lexicon of literature, 3/86. 
and they treated him to paint with tar and then called that animal male "trailer" If a female, like a camel, is told her "trailer". The scabies is said at the first appearance: Naqeb $\left({ }^{43}\right)$. It is said that the well-fed cattle are "The Oblique or Almushawf" $\left({ }^{44}\right)$. The poet said tar, - called for him to say:-

I alqatran and poets are scarbed ...... and in the alqatran for the scarbe is comfortableness $\left({ }^{45}\right)$.

* Henna: kind of the qatran coated with camels, to treat scabies and so on.

\section{Al-Fahal said:}

I have managed to disobey it and it is comprehensive ... of pure qatran $\left({ }^{46}\right)$

In order to prevent the occurrence of this disease in the rest of the animals were to intercept the right animals and serve to the encoded and his spine and thigh, said Alnabghp:

And the guilt of a person and left him ... As the flame which Irion somebody else when he is fallen on his knees $\left({ }^{47}\right)$.

And treated the skin diseases that hit the camel with oil. It is said so: "the kohl. $\left({ }^{48}\right)$ "

${ }^{43}$ ) Amr ibn Bahr bin Mahbub al-Kanani loyalty, Alithi, Abu Osman, famous for the statement, the statement and clarification, the Library and Library of the Crescent, Beirut, 1423, 1/107.

${ }^{44}$ ) Labeed bin Rabia bin Malik, Abu Aqil al-Amiri, DiwanLabeed bin RabiaAmiri, cared for by HamdouTammas, first edition, 1425 - 2004, Dar alMaarifah, p 122

${ }^{45}$ ) Taj al arwos , 13/444

$\left.{ }^{46}\right)$ Al-Asma'i said: "The one who knows his family is the one who misrepresents and humiliates them. Abu Bakr Muhammad ibn al-Qasim al-Anbari, Zaher in the meanings of people's words, Hatem Saleh Al-Daman, First Edition, 1412H, 1992, Al-Resalah Foundation, Beirut, 1/134

${ }^{47}$ ) Ibn Said Andalusian, the euphoria of Tarab in the history of Arab Jahiliyya, the investigation of Dr. Nasrat Abdel Rahman, Al-Aqsa Library, Amman Jordan, p. 569.
It is a disease that was diagnosed by Arabs before Islam, the disease of dabiya, a disease of "camels", and appears in the camels of camels; still eating his sleep until it is eliminated, and the Arabs when you see that disease accelerate in cutting camel camel and said to the camel, which cuts his sleep. $\left({ }^{49}\right)$ :

If he does not deal with the rest of the camels until he kills the animal, then he dies. If the tails are exposed, the birds will click it, the animal will be hurt, and the pain will die.

Her eyes sniff the crows and the marble $\left({ }^{50}\right)$

Perhaps this is what caused the Arabs at that time to be pessimistic of the "Achilles" and some other birds that were landing on the appearance of camels and snorkeling. The poet says:

If we do not know the language of Ibn Majurk, you will be able to fly from al-Araqib, Achila $\left({ }^{51}\right)$

It was a disease that affected the camels and ruled by a disease called Arabs "Swaaf", and was known as a disease that affects camels and spoils. $\left({ }^{52}\right)$

In addition, a pre-Islamic Arab person has had infectious diseases, which the Arabs have warned of the most cautious disease called "inventory", and this disease, if spread among the animals and destroyed it, and they did not have a trick with him and therefore they were warned more cautious. The back of the shank of the animal is magnified and increased even to prevent him from walking and seeking and staying with him until he dies $\left({ }^{53}\right)$. The people of the news that "the jarwood al abdee ", a man of prophet companions from abd qabas.

\footnotetext{
${ }^{48}$ ) Taj al arwos, 3/184.

$\left.{ }^{49}\right)$ DiwanLabeed bin RabiaAmiri, p. 18.

${ }^{50)}$ Taj al arwos , 7/351

${ }^{51}$ ) Taj al arwos , 3/360

$\left.{ }^{52}\right)$ Abu Al-Faraj Al-Maafy Ibn ZakariaIbnYahya AlJaririNahrawani, Al-Jalil Al-Saleh Al-Kafi and Anis Al-Nasafi Al-Shafi, Investigation by Abdul Karim Sami Al-Jundi, First Edition 1426 AH, 2005, Scientific Book House, Beirut, Lebanon, p 475

${ }^{53}$ ) Taj al arwos , 7/491.
} 
But he was called "Garuda" because he fled with his camel to his brothers from "the sons of Sheiban" and his father was sick, so that the disease spread in the camels of his brother and killed her $\left({ }^{54}\right)$, in which the poet says:

\section{Al-Jaroud has been stripped of Bakr ibn Wael}

So it is called the infamous Garuda $\left({ }^{55}\right)$, and treatment: the condition until the blood comes out, and melted from the fat of ostriches, laurel, Shunez and boiling water, single or group, and painted, as well as onion $\left({ }^{56}\right)$.

* The Fault: Dissolution of the nerve so that the joint is separated by its center, and the reason for drinking on fatigue, and treatment of ironing in its place, and dressing with clutches, such as tannery makes it woven of wool, and is like the net, and remains until he is cured. $\left({ }^{57}\right)$

- A disease that afflicts the animals is a disease that is said to be: "the mind", which affects the legs of the animals, and makes them swell, so walk the animals like lame, and most affects the animals in the chapter $\left({ }^{58}\right)$.

${ }^{54}$ ) Jamal al-Din Abi al-Faraj Abdul Rahman bin alJawzi, vaccination of the people of the impact in the eyes of history and walking, Dar al-Arqam ibn Abi alArqam, Beirut, 1997, p. 356, Abu Muhammad Abdullah bin Muslim bin QutaibaDinuri, 1992, Egyptian General Book Organization, Cairo, p. 328.

\section{9)Taj al arwos , 18/73}

${ }^{55}$ ) EmileBadiYaqoub, the detailed dictionary in Shawad al-Arabiya, first edition, 1417 AH - 1996, Dar al-Kuttab al-Ulmiyya, Beirut, 1/468

${ }^{56}$ ) Mohammed bin Abdul QadirAljazairy, elite contract of horses in the Saphnat horses, p. 70

${ }^{57}$ ) Mohammed bin Abdul QadirAljazairy, elite contract of horses in the Saphnat horses, p. 70

${ }^{58}$ ) Taj al arwos, 8/28, Musab bin Mohammed (Abu Bakr) Ben Masood Al KhashaniAljiani Andalusian, Abu Dhar, the short spelling in the explanation of Gharib Sir, correcting Paul Brunel, Scientific Library, Beirut - Lebanon, 1/137
- Proving the lobes: the loosening of the bones under the pomegranate of the cold $\left({ }^{59}\right)$, and treatment of paste the asphalt with cypress and pepper. $\left({ }^{60}\right)$

* Al humiat: $\left({ }^{61}\right)$ useful in the disobedience of the jug and drink sugar cane and dust with oil and cumin, milk and sarcasm and ignorance and alcohol. $\left({ }^{62}\right)$

* Throbbing and heartache: two cough, and benefit them ashes sugar cane with saffron. ${ }^{63}$ )

* Alkun: It is in the joints especially above the knee of the frequent traffic or load of pregnancy, said Ibn al-Roumi:

What we hear when we hear by ear of Plit before it began the space $\left({ }^{64}\right)$. The treatment of the paste of each laxative, such as raisins, grapes of thyme, saffron, figs, chuniz and honey $\left({ }^{65}\right)$.

* Bone precession (Pre-eminence): abscess in the hoof, and treatment: Glue paste, or: wet waffle and the bastard, garlic and wet virgin paste on the wool and fluid with oil may be put $\left({ }^{66}\right)$.

* Altobacco (Calculation): The following is a toothpick, accompanied by slitting and roughness of a wet substance $\left({ }^{67}\right)$, and then treated with a protected probe until it comes

${ }^{59}$ ) Taj al arwos , 18/73.

${ }^{60}$ ) Elite holding horses in the horsemen of horses, p. 70

${ }^{61}$ ) Taj al arwos , 21/290

${ }^{62}$ ) Elite holding horses in the horsemen of horses, p. 70

${ }^{63)}$ Taj al arwos , 25/243

${ }^{64}$ ) Diwan Ibn al-Roumi, 1/4799

${ }^{65}$ )Elite holding horses in the horsemen of horses, p. 70

$\left.{ }^{66}\right)$ Elite holding horses in the horsemen of horses, p. 70 ${ }^{67}$ ) Mohammed benAl-Hassun ben Ali ben Hamdun, Abou Al-Malae, BahaaAldeen Al-Baghdady, Altathkarah Al-Hamdounia, The first edition, 1417 AH, Dar Sadeer, Beirut, 6/364, Jarallah al-Zamakhshri, Rabie al-Abrar and the texts of the good guys, first edition, $1412 \mathrm{AH}$, Al-Amali Foundation, Beirut, 1/120 
out of the fig, yellow water, and treated with ointment, tar, arsenic, lime and urine $\left({ }^{68}\right)$.

* Vowel (Alwaqrah): hidden ulcers in the hoof from the bombardment of a nail or the inflow of an edible substance $\left({ }^{69}\right)$, and treatment by detection and removal of the insole, and clean the substance and the guilt and $\operatorname{tar}\left({ }^{70}\right)$.

* Move the teeth or tooth decay $\left({ }^{71}\right)$ Treatment of puffing and henntate, oil-coated, and pressing with the herb and chuniz $\left({ }^{72}\right)$.

* Cough: and called the owners and affects the camels and horses $\left({ }^{73}\right)$ if the coolness of the process cooked garlic and raisins and cumin and Ntahwa and panic, should be sweetened in honey, although the heat of the eggs soaked vinegar to soften, and stick with oil and hot water.

* Shankah: abscess accentuates the congestion of the wind and the like in the shoulder or broth, treated with fractures $\left({ }^{74}\right)$.

* Sores and Dovrat: from the saddle of the saddle or the passenger $\left({ }^{75}\right)$, treatment of purification and holding seeds such as tannins, pomegranate, shab and henna is the most beneficial, and most of all purification with hot water and soap and oil oil gas, and also benefits from itching and scabies, and Akhala: salt Andrani Ntron Pearl Sugar sugar plant, patina, aging stone, burnt house, pepper, nochader, saffron, camphor berries, and benefiting the plagiarism of mugla, whiteness and pterygium $\left({ }^{76}\right)$.

* Obliqueness: It is a twisting of the horse lists $\left({ }^{77}\right)$ Treat with milk and dates, barley, chicken

${ }^{68}$ ) Elite holding horses in the horsemen of horses, p. 70

${ }^{69}$ ) Taj al arwos , 14/378

$\left.{ }^{70}\right)$ Elite holding horses in the horsemen of horses, p. 70

$\left.{ }^{71}\right)$ Reinhart Peter Ann Dozzi, Supplement of Arabic Dictionaries, 3/143

${ }_{72}^{72}$ Elite holding horses in the horsemen of horses, p. 70

${ }^{73}$ )Taj al arwos, 3/519

${ }^{74}$ ) Elite holding horses in the horsemen of horses, p. 70

${ }^{75}$ ) The Sun of Science and the Medicine of the Arabs from Kaloum, 8/5456

${ }^{76}$ )Elite holding horses in the horsemen of horses, p. 70

${ }^{77}$ )Majd al-Din Abu Taher Mohammed bin Yaqoub Al-

Firouzabadi, The Surrounding Dictionary, Achieving broth and snuff, and drink the marketing of buckthorn, apple, cabbage, leek and vinegar, and gardener from him $\left({ }^{78}\right)$. Al-Qalqashandi mentioned a number of diseases that affected the Arab population including:

* Exostosis; it is a tumor that affects the animal in the last man, such as hair removal goes hair is said to be a fracture that affects the horses in her hands and legs. $\left({ }^{79}\right)$

- Dixie, a tumor that is in the hoof in hooves of animals $\left({ }^{80}\right)$

* The trunk; it is the spasm of the nerve of his wrist until his hoop turns into a walk on the face of the hoof $\left({ }^{81}\right)$.

* Peel: this is a gross defect; and the fistula which is called by the venerable public - is a disease that occurs in the eagle of the animal, and if the blood is cut off from it $\left({ }^{82}\right)$.

* Al'iidara: it is a defect that is so ugly as to make riding a horse that has this defect $\left({ }^{83}\right)$.

- Hida (Alhalud), a severe disease that pierces its position from the body of the animal sheds yellow water. If the fire is coagulated and opened to another place, it is still so that the animal is rotted; it is an obscene defect $\left({ }^{84}\right)$.

From insects that were hurting the animals in the Arab environment blue flies and called by the Arabs at the time (poets), and perhaps a lot of blessings so that the people cannot camels to mingle with the day or to ride something from them and leave it to the night as it stabs camels in the control and around him and Under the sin,

the Office of Heritage Investigation in the Foundation of the Message, under the supervision of: Mohamed Naeem Al-Erqasusi, 8th Edition, 1426H, 2005

${ }^{78}$ ) Elite holding horses in the horsemen of horses, p. 70

${ }^{79}$ )Sobh al-A'shi in the construction industry, 2/30, the arbitrator and the great ocean, 2/101

$\left.{ }^{80}\right)$ Sobh al-A'shi in the construction industry, 2/30, the bride's crown of the jewels of the dictionary, 16/60

${ }^{81}$ )Sobh al-A'shi in the construction industry, 2/30, the bride's crown of the jewels of the dictionary, $9 / 63$

${ }^{82}$ )Subh al-A'shi in the construction industry, 2/30

$\left.{ }^{83}\right)$ Sobh al-A'shi in the construction industry, 2/30, Sanan al-Arab, 4/15

${ }^{84}$ )Subh al-A'shi in the construction industry, 2/30 
the abdomen and the axillaries, and they do not wear anything if it is only with tar and it flies on camels until you hear her voice loud $\left({ }^{85}\right)$.

- Tick: a small insect chasing the camels and stick to the bodies and live on sucking the blood of them $\left({ }^{86}\right)$ said $\mathrm{Al}$ a khtal

Named after the heels of human bones ... Your father was named Scarab

And your shop from Wael ... replace ticks from Ast Camel $\left({ }^{87}\right)$.

- The nipple, which is a small insect that affects the skins of the upper and lower shafts and feeds on it, has treated the Arabs in ignorance of this disease that they Bbbg places of injury, which remains thin after the insect is eliminated $\left({ }^{88}\right)$.

- Lice, a small insect-like tick that harms both human and animal, is generated on the body when pushed blindness to the outside $\left({ }^{89}\right)$.

The Arabs knew before Islam the treatment of these insects by sintering, which is to take something from my nits, ace and siddur, and something of gum, and make it in the roots of poetry, so that the hair cannot sweat and sweat, and enter the dust, Vikhm $\left({ }^{90}\right)$.

${ }^{85}$ )Abu Hassan Ali bin Ismail bin SidhiMursi, the arbitrator and the vast ocean, the investigation of Abdel Hamid Hindawi, Dar al-Kuttab al-Ulmiyya, Beirut, $2000,1 / 368$

${ }^{86}$ ) Abu Hassan Ali bin Ismail bin Sidh, arbitrator and the Great Ocean, 6/305.

$\left.{ }^{87}\right)$ Mohammed bin Salam Al-Jamhi, layers of stallion poets, the realization of Mahmoud Mohammed Shaker, Dar Madani - Jeddah, 2/462

$\left.{ }^{88}\right)$ Mohammed bin Musa bin Isa bin Ali al-Dumeiri, Abu al-stay, Kamal al-Din al-Shafei, the life of the great animal, second edition, 1424 e, Scientific Book House, Beirut, 1/327

${ }^{89}$ ) Abulhassan Ali bin Ismail bin Sidhi al-Mursi, ad hoc, investigation of Khalil Ibrahim Jafal, first edition 1417H 1996, House of Revival of Arab Heritage Beirut, 2/318

$\left.{ }^{90}\right)$ Detailed in the history of the Arabs, 8/206
Also known as the Arabs at the time Zaoq, a treatment similar to melted silver, a hot humid in the fourth degree, if mixed with vinegar and maimed by infected animals scabies and itching, and if added to the vinegar is a treatment kills lice and rats and ticks to overheat, and killing kills the mouse if thrown In food $\left({ }^{91}\right)$.

One of the veterinary diseases in which pre-Islamic Arabs excelled was that they purified the uterus of the horse or the camel from the sperm if it was not honest, and they remove the child from the belly of the horse or camel and express it in the word "Massi" $\left({ }^{92}\right)$. At the time, the Arabs knew about the animals' intestines, which are the types of the face, which is to pull the nerve of the testicles of the testicles out of the penis, even if the egg is rare and the testicle is sharpened and the stomach is softened until it satisfies it. At that time, it withers and degenerates and tails and stabs until its forces reach and drain the sewage. And prevent them from abounding, torturing or coagulating.

And some of them may be severe and nerve and severity of the contractions and the contract string very severe Vtl if left to do so and eat or eat and prevent him to pay him the food is soon to be cut off and fall. And from it is spread, which is the spread of the eggs $\left({ }^{93}\right)$.

The Arabs deliberately castrated beasts and cattle because they believed that estrangement in the events of cattle and sheep especially let the meat license and dowry sweetness, his testicles after the old did not strengthen his sisters after the strength of the strength of the heart and the best character of the offspring was called a little Persian called Thrbkht means that he was a wet eunuch And the eunuchs of its spoons I carry to the fat for non-agitation and preaching and the departure of its forces with the water of the trip and the abundance of ambassadors inherited weakness and wasting in all animals, and the Arabs belong to the

$\left.{ }^{91}\right)$ Nashwan bin Said al-Humeiri, Shams al-Uloom and the medicine of the words of the Arabs of Alkloum, $5 / 2872$

$\left.{ }^{92}\right)$ Mohammed bin Abdullah bin Abdullah bin Malik alTai al-Jayani, the completion of flags triangulation speech, the achievement of Saad bin Hamdan alGhamdi, Mecca, 1404 AH 1984, 2/636

${ }^{93}$ ) Al-Jahiz, Animal 1/130 
camels of the camels lest eat each other and keep what was the finest and the most virulent $\left({ }^{94}\right)$.

It was the most famous of those who committed at the time Hakam bin Abi al-Aas $\left({ }^{95}\right)$ and famous for the sheep sheep, and those who knew among the Arabs at that time know Bitarah "Aas ibn Wael" $\left({ }^{96}\right)$, and was

${ }_{95}^{94}$ Al-Jahiz, Animal 1/131

$\left.{ }^{95}\right)$ Hakam ibn Abi al-Aas ibn Umayya ibn Abd Shams al-Qurashi Umayyad, uncle Othman bin Affan, and the father of Marwan, the safest day of the Conquest, and the residence of the city, and the Prophet (peace and blessings of Allaah be upon him) denied him to Taif, and then he was returned to Medina in the caliphate of 'Uthman and died with it - may Allah be pleased with him. Muhammad bin Yusuf al-Salhi al-Shami, the ways of guidance and guidance, in the biography of the best of the slaves, and mentioned his virtues and the flags of his prophecy and his actions and conditions in principle and the rest, the investigation and comment Sheikh Adel Ahmed Abdul Muqawad, Sheikh Ali Mohamed Moawad, first edition 1414 - , Dar al-Kuttab al-Sallami, Beirut, Lebanon, 10/221, Shams al-Din Abu Abdullah Muhammad ibn Ahmad bin Othman Ibn Qaymaz Me, the history of Islam and the deaths of celebrities and the media, the achievement of Omar Abdel-Salam destruction, second edition, 14131993 - AD, Arab Book House, Beirut, 3/365

${ }^{96}$ )Aas (or Ausi) bin Wael bin HashimSakhi, Quraish: one of the rulers in the ignorance. Ndima to Hisham ibn al-Mughira. And realized Islam, and remained in shirk. $\mathrm{He}$ is one of the (mockers) and of the (heretics) who died infidels and pagans. And was on the head of the shares of the shares, in the war (Fajr) - 33 BC AH 551 AD - It was said in the news of his death: A day on his trip, and with his sons, walking, and landed in a reef, when he put his foot on the ground, shouted, Nothing. And his foot swelled until it became like the neck of the camel, and died, and they said: Bite the earth! AlZubaidi said: He prevented Omar ibn al-Khattab from Quraysh, when he showed the age of Islam. He is the father of Amr ibn al-Aas, the companion of Fateh of Egypt.

See: Abu al-Qasim Ali ibn al-Hasan ibn Hibat Allah known as Ibn Asaker, History of Damascus, Amr ibn al-Din al-Amroi, Dar al-Fikr for printing, publishing and distribution, $1415 \mathrm{AH}-1995,45 / 109$, Hussain bin Mohammed bin Hassan al-Dayar Bakri, the date of Thursday in the circumstances of the souls of the soul, Dar Sader - Beirut, 1/353, Khairuddin Ben Mahmoud Bin Muhammad bin Ali bin Fares, ZarkaliDamasche, dealing with horses and camels. His son Amr ibn al-Aas was a butcher $\left({ }^{97}\right)$. Al-Bayatra excelled in their knowledge of horses and camels, because they are the most valuable money of the Arabs $\left({ }^{98}\right)$. because the animal was the cornerstone of the life of the first Arab in their country desert and the profession of grazing and trade and the sale of animal economy, which is the foundation of their lives, including food from milk and meat, including housing tents and clothing and therefore they are fighting to protect the tribe and where the sport horses and camel desert ship, it was brutal. They studied printing to protect themselves and their pets from it, they wrote the most beautiful poetry and the most impressive writings literary.

The literature on veterinary medicine in the Arab heritage is rich and strong. There is no doubt that it was based mostly on the experiences of the former and what they inherited from their parents and grandparents and what they gained from experience, experience, daily simulation and living with the animal. They have written in various veterinary arts, including:

-Benefits established in the science of veterinary, for Ali bin Abdul Rahman bin Hazil al-Fizari $\left({ }^{99}\right)$

- The singer in the veterinary, Omar bin Yusuf bin Omar bin Ali bin Rasul, Abu Hafs, Muhammed al-Din, King Ashraf $\left({ }^{100}\right)$

-Equestrian and horse therapy, for the religion of bacterium spears Khazandari deputy (deceased 711 Hijri)

•Equestrian and Veterinary, author Baghdadi $\left({ }^{101}\right)$.

Flags, edition: Fifteenth, 2002, Dar al-Ilm for millions, $3 / 247$.

$\left.{ }^{97}\right)$ Muhammad bin Musa bin Isa bin Ali al-Dumeiri, Abu al-Waqdah, Kamal al-Din al-Shafi'i, The Life of the Great Animal, Second Edition, 1424 AH, By Dr. Wadad Al-Qadi, First Edition, 1408 AH-1988, Dar Sader, Beirut, 5/43.

$\left.{ }^{98}\right)$ Detailed in the history of Arabs before Islam, 16/52

${ }^{99}$ ) Detailed in the history of the Arabs before Islam, $16 / 52$

${ }^{100}$ )aliielam , 4/29 
-Horse, its characteristics, types and ways, for the Apostolic Son of David $\left({ }^{102}\right)$.

-A book full of industries (Veterinary and Hurghada), to Abu Bakr bin Al-Badr Bitar $\left({ }^{103}\right)$.

-The Book of Horses and Baitra, by Jacob the son of Isaac the Canadian $\left({ }^{104}\right)$.

-Horses and their predecessors, their genealogies, their places, their faults, their desecration, and the descent to their horse, to Abdullah bin Muhammad al-Tozi $\left({ }^{105}\right)$.

-Singer in the veterinary, to the king Ashraf Ghassani $\left({ }^{106}\right)$.

-The book of celebration in the fulfillment of what the horse, the father of Abdullah bin Mohammed bin Radwan bin Arqam Nimeiri Valley Ashi $\left({ }^{107}\right)$.

- Insight in the science of veterinary, to Muhammad ibn Abi Bakr bin Mohammed bin Abi Bakr bin Hassan bin Ali Persian $\left({ }^{108}\right)$.

\section{CONCLUSION}

The animals were the mainstay of the first Arab human life, where their country was desert and their main occupation was grazing and their economy depended mainly on the sale of animals. As well as they living on milk and meat of animals and take advantage of their skin and wool for housing and clothing. Therefore, preIslamic Arabs had great interests in veterinary

\footnotetext{
${ }^{101)}$ aliielam, 5/69

${ }^{102}$ ) Omar bin Rida bin Mohammed Ragheb bin Abdul Ghani Kahala Damascus, Dictionary of Authors, Muthanna Library - Beirut, House of Revival of Arab Heritage, Beirut, 7/91

${ }^{103}$ ) Mustapha bin Abdullah, writer of the Chalabi of Constantinople famous as Haji Khalifa or Haj Khalifa, revealed suspicions about the names of books and arts, Muthanna Library - Baghdad, 1941, 2/1380

${ }^{104}$ )aliielam, 7/145

105) Mohammed ibn Ishaq Abu al-Faraj al-Nadim, alFuhurst, Dar al-Maarifah, Beirut, 1398-1978,

$\left.{ }^{106}\right)$ Zirkali, aliielam, 5/69

${ }^{107}$ ) Omar Reza Kahala, Dictionary of Authors, 9/318

${ }^{108}$ ) Omar Reza Kahala, Dictionary of Authors, 9/117
}

medicine, which was not preceded by any of the previous nations.

The Arabs had independent and separate medical practices away from the gods and magic. These practices were brought to them by their own experiences and their minds were inspired by their environment. In addition, the Arabs followed in the treatment of diseases several methods depending on what is in their environment, treated many of them in different ways and every disease they called a name. The Arabs also treated reddish disease with psoriasis, as well as treating the disease of discord in plants. From this we conclude that the Arabs have different veterinary medical treatments depending on the disease and its danger to the animals.

\section{MARGINS}

1. Jawad Ali, detailed in the history of the Arabs before Islam, fourth edition, $1422 \mathrm{AH} /$ 2001, Dar al-Saqi, 13/112, Mohammed Bayoumi Mehran, studies in the history of ancient Arabs, second edition,

2.Mohammed bin Abdul Qadir al-Jazairi, the elite of the pyramids in Al-Safnat Al-Jiyad, Al-Ahlia, Beirut, $\mathrm{p}$

3. Dr. Jawad Ali, detailed in the history of the Arabs before Islam, 13/117

4. Dr. Jawad Ali, detailed in the history of the Arabs before Islam, 13/117

5.Mohammed bin Mohammed bin Abdul Razzaq alHusseini, Abu al-Fayd, nicknamed Bremerta, alZubaidi, Taj al-Arous from Jawahar al-Kalamun, investigation by a group of investigators, Dar alHidayah, 12/341 Saqr

6. Dr. Jawad Ali, detailed in the history of the Arabs before Islam, 8/268

7. Hussain bin Ahmed bin Hussein al-Zuzani, Abu Abdullah, Explanation of the seven pendants, first edition 1423 - 2002, House of Revival of the Arab heritage, p. 102, Georgy Zidane, the history of Islamic civilization, Cairo, 1958, 3/12-15. 
8. Tawfiq Pro, History of the Ancient Arabs, Second Edition, 1422 AH / 2001 AD, Dar al-Fikr, p. 278

9. Abul-Hasan, Nur al-Din Ali bin Abi Bakr bin Sulaiman al-Haythami, the sources of the thirst to Zuwaid Ibn Hibban, the investigation of Hussein Salim Asad al-Darani - Abdo Ali al-Kushak, first edition (1990-1992) Arab Culture, Damascus, 5/430

10. Taj al arwos, 15/243, "Al-Athez."

11. Detailed in the history of the Arabs before Islam, $16 / 27$

12. Amr ibn Bahr ibn Mahbub al-Kanani with loyalty, al-Leithi, Abu Othman, famous animal, I 21424 e, scientific bookstore - Beirut, 1/214

13. Al-Jahiz, Animal, 7/53

14. Detailed in the history of the Arabs before Islam, $16 / 52$

15. Ismail bin Mohammed Amin bin Mir Selim alBabani al-Baghdadi, the gift of those who know the names of the authors and the effects of the classifieds, the House of Revival of Arab Heritage Beirut, Lebanon, $1 / 614$

16. Mustapha bin Abdullah, writer of the Chalabi of Constantinople, famous as Haji Khalifa or Haj Khalifa, revealed suspicions of the books and the arts, Al Muthanna Library, Baghdad, 1941, 2/1740

17. Shahabuddin Abu Abdullah Yacout bin Abdullah Al-Roumi Al-Hamwi, Dictionary of Literary Criticism, Ihsan Abbas, First Edition, 1414H-1993, Dar Al-Gharb Al-Islami, Beirut, 6/2708

18. Abulhassan Ahmed Ibn Fares, A Dictionary of the Language Scale, An Investigation of Abdel Salam Mohammed Haroun, C3, Dar Al-Fikr (Beirut-Lat), p. 407

19. Ibn Masur Lassan, The Arabs, 1, p. 554

20. Abu Ali Al Hussein Bin Ali Ibn Sina, Law in Medicine, Al Muthanna Library (Baghdad - LA), C1, p. 3.
21. Al-Baghdadi, Abdel-Qader bin Omar, The Book of Literature and the Heart of the Sanab Al-Arab, An Investigation and Explanation of Abdulsalam Muhammad Haroun, Fourth Edition, 1418H - 1997, AlKhanji Library, Cairo, 9/295

22. Imad al-Din Isma'il Abu al-Fida (d. 732 AH / 1331 $\mathrm{CE}$ ), the acronym in the news of humans, (No.

23. Ahmed bin al-Qasim bin Khalifa bin Younis alKhazraji Muwafaq al-Din, Abu al-Abbas Ibn Abi Suqtah, eyes of the news in the strata of doctors, investigation by Dr. Nizar Reza, Library of Life Beirut, p. 161

24. Abu Dawood Sulaiman bin Hassan Al Andalusi Mahrouf Ibn Jahl, Layers of Doctors and Elders, Beirut, The Foundation of the Message, 1405 AH / 1985, p. 54

25. Detailed in the history of the Arabs before Islam, $16 / 16$

26. Ibn Manzoor, Sanson Al-Arab, Dar Sader, Beirut, Article (Petr), 4 / 69-70

27. Abu Al-Hussein Ahmed bin Fares bin Zakaria, Dictionary of Language Standards, the investigation of Abdel Salam Mohammed Haroun, published by the Union of Arab Writers, I in 1423 e / 2002. , P. 247, Nashwan bin Said Al-Hameiri Yemeni, Shams science and medicine Kalam Arabs of Klum, investigation: d. Hussein bin Abdullah Al-Omari - Mutahar bin Ali AlIryani - d. Yousef Mohamed Abdullah, First Edition, 1420 - 1999, Contemporary Thought House (Beirut Lebanon), Dar Al Fikr (Damascus - Syria), p. 562. The aortic disease takes in the humerus.

28. Reinhart Peter Ann Dozzi, supplement of Arabic dictionaries, transcribed to Arabic and commented by Mohammed Salim Al-Nuaimi, Jamal Al-Khayat, published by the Ministry of Culture and Information, Republic of Iraq, First Edition, 1979-2000, 1/367

30.Ibrahim Mustafa Ahmed Al-Zayat Hamid AbdelQader Mohammed Al-Najjar, the dictionary of the mediator, the realization of the complex of Arabic language, published Dar al-Dawa, 1/79 
31.Abu al-Tayyib Muhammad Siddiq Khan bin Hassan bin Ali Ibn Lutif al-Husseini al-Bukhari al-Qunuji, Abjad al-Uloom, first edition 1423 AH, 2002, Dar Ibn Hazm, p. 314

31. Mohammed bin Mohammed bin Ahmed bin Abizaid ibn al-Akhwa, al-Qurashi, Diaa al-Din, the landmarks of the request in the request of Hesba, Dar al-Fonoon, p. 152, Abdul Rahman bin Nasr bin Abdullah, Abu Najeeb, Jalal al-Din al-Adawi Shizari Shafi'i, In the request of the honorable Hesba, i Press of the Committee of authorship, translation and publication, p. 82

32.Detailed in the history of the Arabs before Islam, 16 / 50-52

33. Ahmed bin Ali bin Ahmed Al-Fazzari AlQalqashandi, Subh Al-A'shi, in the construction industry,

34. Abu Bakr Muhammad ibn al-Hasan bin Duraid, derivation, investigation of Abdul Salam Mohammed Harun, third edition, Al-Khanji Library, Cairo, p. 498

\section{Taj al arwos , 28/307}

36. Abu Nasr Ismail bin Hammad Al-Jawhari AlFarabi, Al-Sahah Taj Al-Luhah and Saheeh Al-Arabiya, Investigation of Ahmed Abdul Ghafoor Attar, Fourth Edition 1407 H-1987, Dar Al-Ilm for Millions - Beirut, 2/638, Ahmad Bin Fares Bin Zakaria Al-Qazwaini AlRazi , Study and investigation Zuhair Abdul Mohsen Sultan, second edition 1406 H - 1986, the Foundation letter, Beirut, 1/250

37. Mohammed bin Abdul Qadir al-Jazairi, the elite contract of the horses in the saffron horses, p. 70

Dr. Ibrahim Anis, Dar al-Shaab Foundation for Journalism, Printing and Publishing, Dr. Ibrahim AlAnas, Cairo, 1424H - 2003, 3/86

38.Abu Al-Hussein Ahmed bin Fares bin Zakaria, Dictionary of Language Standards, the investigation of Abdul Salam Mohammed Harun, the first edition 1399 - 1979, Dar al-Fikr, 2/78
39.Abu Bakr Mohammed bin al-Hasan bin Duraid alAzdi, the mass of language, a symbolic investigation Mounir Baalbaki, first edition, 1987, Dar al-Ilm for millions - Beirut, 2/960

41. Mohammed bin Mohammed bin Abdul Razzaq alHusseini Abu al-Fayadh, alias al-Zubaidi, the crown of the bride from the jewels of the dictionary, 17/385, Abu Hassan Ali bin Ismail bin Sidhi Mursi, the arbitrator and the Great Ocean, 1/368

42. Nashwan bin Said al-Humeiri, Shams al-Uloom and the medicine of the words of the Arabs from Al-Kalum, 6/3328, Abu Ibrahim Ishaq ibn Ibrahim ibn al-Husain al-Farabi, lexicon of literature, 3/86

43. Amr bin Bahr bin Mahbub al-Kanani loyalty, AlLeithi, Abu Othman, famous for the statement, clarification and clarification, the Library and Library of the Crescent, Beirut, 1423, 1/107

44. Labeed bin Rabia bin Malik, Abu Aqil al-Amiri, Diwan Labeed bin Rabia al-Ameri, taken care of by Hamdou Tammas, first edition, 2004, Dar al-Maarifah, p. 122

45. Taj al arwos of the Qamuse, 13/444

46. Al-Asma'i said: "The one who cares for his family is the one who abhors them.

Abu Bakr Muhammad ibn al-Qasim al-Anbari, Zaher in the meanings of people's words, Hatem Saleh AlDaman, First Edition, 1412H, 1992, Al-Resalah Foundation, Beirut, 1/134

47. Aben Said Al-Andalusian, the euphoria of Tarab in the history of the Arab Jahiliyya, by Dr. Nusrat Abdel Rahman, Al-Aqsaa library, Amman - Jordan, p. 569.

48. Taj al arwos from Jewels Dictionary, 184/3.

49. Diwan Labid bin Rabia al-Amiri, p. 18.

50. Taj al arwos from Jewels Dictionary, 351/7.

51. Taj al arwos from Jewels Dictionary, 360/3.

52. Abu Al-Faraj Al-Ma'afi Ibn Zakaria Ibn Yahya AlJariri Nahrawani, Al-Jalil Al-Saleh Al-Kafi and Al- 
Anis Al-Nasafi Al-Shafi, Investigation by Abdul Karim Sami Al-Jundi, First Edition, 1426H (2005).

53. Taj al arwos from Jewels Dictionary, 491/7

54. Jamal al-Din Abi al-Faraj Abdul Rahman Ibn alJawzi, vaccination of the people of impact in the eyes of history and the path, Dar al-Arqam ibn Abi alArqam, Beirut, 1997, p. 356, Abu Muhammad Abdullah bin Muslim bin Qutaiba Dinuri, knowledge, Second, 1992, Egyptian General Book Authority, Cairo, p. 328

55. Emile Badi Yaqoub, The Detailed Dictionary in Shawad Al Arabiya, First Edition, 1417H - 1996, Dar Al-Kuttab Al-Alami, Beirut, 1/468

56. Mohammed bin Abdul Qadir al-Jazairi, elite contract of the horses in the sapnets horses, p. 70

57. Mohammed bin Abdul Qadir al-Jazairi, the elite contract of the horses in the saffron horses, p. 70

58. Taj al arwos, 8/28, Mus'ab Ibn Muhammad (Abu Bakr), Ibn Masood al-Khashani, Al-Jiani Andalusi, Abu Dhar,

59.Taj al arwos from Jewels Dictionary , 18/73

60. The elite holding the horses in the horsemen of the horses, p. 70

61. Taj al arwos from Jewels Dictionary, 21/290

62. The elite holding the horses in the horsemen of the horses, p. 70

63. Taj al arwos from Jewels Dictionary, 25/243

64. Diwan Ibn al-Roumi, 1/4799

65. The elite holding the horses in the horsemen of the horses, p. 70

66. The elite holding the horses in the horsemen of the horses, p. 70

67. Mohammed bin al-Hasan bin Muhammad bin Ali bin Hamdoun, Abu al-Ma'ali, Bahaa al-Din alBaghdadi, Hammadiyya ticket, first edition, 1417 AH,
Dar Sader, Beirut, 6/364, Jarallah al-Zamakhshari E, Al-Amali Foundation, Beirut, 1/120

68.The elite holding the horses in the horsemen of the horses, p. 70

69. Taj al arwos from Jewels Dictionary, 14/378

70. The elite holding the horses in the horsemen of the horses, p. 70

71. Reinhart Peter Ann Dozzi, Supplement of Arabic Dictionaries, 3/143

72. The elite holding the horses in the horsemen of the horses, p. 70

73. Taj al arwos from Jewels Dictionary, $3 / 519$

74. The elite holding horses in the horsemen of horses, p. 70

75. Shams al-Uloom and the medicine of the words of the Arabs from Al-Kalum, 8/5456

76. The elite holding the horses in the horsemen of the horses, p. 70

77. Majd al-Din Abu Taher Muhammad bin Yaqoub Al-Firouzabadi, The Surrounding Dictionary, Achieving the Office of Heritage Investigation at AlResala Foundation, under the supervision of: Mohammed Naeem Al-Arqasusi, 8th Edition, 2005.

78. The elite holding horses in the horsemen of horses, p. 70

79. Sobh al-A'shi in the construction industry, $2 / 30$, the arbitrator and the great ocean, 2/101

80. Sobh al-A'shi in the construction industry, $2 / 30$, bride's crown of the jewels of the dictionary, 16/60

81. Sobh al-A'shi in the construction industry, 2/30, Taj al arwos of the jewels of the dictionary, 9/63

82. Sobh al-A'shi in the construction industry, 2/30

83. Sobh al-A'shi in the construction industry, $2 / 30$, Sanan al-Arab, 4/15 
84. Sobh al-A'shi in the construction industry, $2 / 30$

85. Abu Hassan Ali bin Ismail bin Sayed al-Morsi, arbitrator and the vast majority, the investigation of Abdul Hamid Hindawi, Dar books

86. Abu Hassan Ali bin Ismail bin Sidh, arbitrator and the Great Ocean, 6/305

87. Mohammed ibn Salam al-Jumhi, Tabbiqat Pohoul al-Sha'araa, investigation by Mahmoud Muhammad Shaker, Dar al-Madani, Jeddah, 2/462

88. Mohammed bin Musa bin Isa bin Ali al-Dumeiri, Abu al-staya, Kamal al-Din al-Shafi'i, the life of the great animal, second edition, 1424 AH, Dar al-Kuttab al-Alami, Beirut, 1/327

89. Abulhassan Ali bin Ismail bin Sayyid al-Mursi, The Custom, The Investigation of Khalil Ibrahim Jafal, First Edition 1417H 1996, House of Revival of Arab Heritage - Beirut, 2/318

90. Detailed History of the Arabs, 8/206

91. Nashwan bin Said al-Humeiri, Shams al-Uloom and al-Kalam al-Arab al-Kalum, 5/2872

93. Mohammed bin Abdullah bin Abdullah bin Malik al-Tai al-Jayani, completion of flags triangulation speech, the achievement of Saad bin Hamdan alGhamdi, Mecca, 1404 AH 1984, 2/636

94. Al-Jahiz, Animal 1/130

\section{Al-Jahiz, Animal 1/131}

96. Hakam bin Abi al-Aas bin Umayya bin Abdul Shams al-Qarashi Umayyad, the uncle of Othman bin Affan, and the father of Marwan, the safest day of conquest, and the city, and then denied by the Prophet peace be upon him to Taif, and then returned to the city in the succession of Osman and Matt by - The first edition, 1414 - 1993, by Sheikh Adel Mohammed Abdul Muqawad, Sheikh Ali Muhammad Muawad, the first edition of the book, M, Dar al-Kuttab al-Aslami Beirut - Lebanon, 10/221, Shams al-Din Abu Abdullah Mohammed bin Ahmed bin Othman Ibn Qaymaz Wahbi, the history of Islam and the deaths of celebrities and the media, the achievement of Omar Abdel-Salam destruction, second edition, 14131993 - AD, Arab Book House, Beirut, 3/365

97. Al-Aas (or Ausi) is the son of Wa'el ibn Hashim alSakhmi, of Quraish: one of the rulers in the Jaahiliyyah. Nidima was the son of Hisham ibn al-Mughira. And realized Islam, and remained in shirk. He is one of the (mockers) and of the (heretics) who died infidels and pagans. And was on the head of the shares of the shares, in the war (Fajr) - 33 BC AH 551 AD - It was said in the news of his death: A day on his trip, and with his sons, walking, and landed in a reef, when he put his foot on the ground, shouted, Nothing. And his foot swelled until it became like the neck of the camel, and died, and they said: Bite the earth! Al-Zubaidi said: He prevented Omar ibn al-Khattab from Quraysh, when he showed the age of Islam. He is the father of Amr ibn al-Aas, the companion of Fateh of Egypt. See: Abu alQasim Ali ibn al-Hasan ibn Hibat Allah known as Ibn Asaker, History of Damascus

Amr ibn al-Din al-Amroi, Dar al-Fikr for printing, publishing and distribution, $1415 \mathrm{AH}$ - 1995, 45/109, Hussain bin Mohammed bin Hassan al-Dayar Bakri, the date of Thursday in the circumstances of the souls of the soul, Dar Sader - Beirut, 1/353, Khairuddin Ben Mahmoud Bin Muhammad bin Ali bin Fares, Zarkali Damasche, Flags, edition: Fifteenth, 2002, Dar al-Ilm for millions, $3 / 247$

98. Mohammed bin Musa bin Isa bin Ali al-Dumeiri, Abu al-Waqqah, Kamal al-Din al-Shafi'i, The Life of the Great Animal, ed. And ammunition, the investigation of Dr. Wadad al-Qadi, first edition, 1408 AH - 1988, Dar Sader - Beirut, 5/43

99 .Detailed in the history of the Arabs before Islam, $16 / 52$

100. Aliielam, 4/299

101.Aliielam, 5/69

102. Aliielam, $7 / 145$

103.Omar Bin Rida Bin Mohammed Ragheb Bin Abdul Ghani Kahala Al-Damascus, Dictionary of Authors, Al 
Muthanna Library, Beirut, Revival of Arab Heritage, Beirut, 7/91

104. Mustafa bin Abdullah, writer of the Chalabi of Constantinople, famous as Haji Khalifa or Haj Khalifa, revealed suspicions about the names of books and arts, Al Muthanna Library, Baghdad, 1941, 2/1380

105. Aliielam, $7 / 145$

106. Mohammed ibn Ishaq Abu al-Faraj al-Nadim, alFuhurst, Dar al-Maarifah - Beirut, 1398-1978, 1/85

107. Al-Zarkali, Aliielam, 5/69

108. Omar Reza Kahala, Dictionary of Authors, 9/318

109. Omar Reza Kahala, Dictionary of Authors, $9 / 117$

\section{SOURCES AND REFERENCES:}

1. Ibrahim Mustafa Ahmed Al-Zayat Hamed Abdul Qader Mohammed Al-Najjar, the dictionary of the mediator, the realization of the Arabic language complex, published Dar al-Dawa

2. The Andalusian son of Sa'id, the euphoria of rapture in the history of Arab Jahiliyya, by Dr. Nusrat Abdel Rahman, Al-Aqsa Library, Amman, Jordan

3. Ibn Manzoor, San'a Al Arab, Dar Sader, Beirut

4. Abu Ibrahim Ibrahim Ishaq bin Ibrahim bin AlHussein Al-Farabi, (350 e), a dictionary of the Diwan of literature, the investigation of Dr. Ahmed Mokhtar Omar, review: Dr. Ibrahim Anis, Dar Al-Shaab Foundation for Press, Printing and Publishing, Cairo, $1424-2003$

5. Abu al-Hasan Ali bin Ismail bin Sayyid al-Morsi (p. $458 \mathrm{e}$ ): the arbitrator and the vast majority, the investigation of Abdel-Hamid Hindawi, Dar al-Kuttab al-Alami, Beirut, 2000

6. Abul-Hassan al-Hasan al-Haythami (807 AH), the sources of the thirst to Zuwaid Ibn Hibban, investigation by Hussein Salim Asad al-Darani - Abdo Ali al-Kushak, first edition, (1990-1992) M), House of Arab Culture, Damascus
7. Abu Al-Hussein Ahmed bin Fares bin Zakaria, Dictionary of Language Standards, the investigation of Abdul Salam Mohammed Haroun, published by the Union of Arab Writers, I in 1423 AH / 2002.

8. Abu al-Tayyib Muhammad Siddiq Khan bin Hassan bin Ali Ibn Lutaf Allah Husseini al-Bukhari al-Qanuji (1307 AH), Abjad al-Uloom, first edition $1423 \mathrm{AH}-$ 2002, Ibn Hazm House

9. Abu al-Faraj al-Ma'afi Ibn Zakaria ibn Yahya alJariri al-Nahrawani (d. $390 \mathrm{AH}$ ), the good and good guide, and the wise scholar, the investigation of Abdul Karim Sami al-Jundi, the first edition, 1426H.

10. Abu al-Qasim Ali ibn al-Hasan bin Heba Allah known as Ibn Asaker (d. 571 e), the history of Damascus, the investigation of Amr ibn Fine AlOmrawi, Dar Al-Fikr for printing, publishing and distribution, 1995.

11. Abu Bakr Muhammad ibn al-Hasan bin Duraid alAzdi (321 e): Derivation, the investigation of Abdul Salam Mohammed Harun, third edition, Al-Khanji Library, Cairo

12. Abu Bakr Muhammad ibn al-Qasim al-Anbari, alZaher in the meanings of the words of people, investigation: d. Hatem Saleh Al-Daman, First Edition, 1412H, 1992, Al-Resalah Foundation, Beirut

13. Abu Hayyan al-Tawhidi, Ali bin Mohammed bin Abbas (c. $400 \mathrm{AH}$ ), Insights and Ammunition, investigation by Dr. Wadad al-Qadi, first edition, 1408, 1988, Dar Sader, Beirut

14. Abu Dawood Sulaiman bin Hassan Al Andalusi Mahrouf Ibn Jalahl, Layers of Doctors and Elders, Beirut, Al-Resala Foundation, 1405 AH / 1985

15. Abu Muhammad Abdullah bin Musallam bin Qutaiba al-Dinuri (d. 276), knowledge, the investigation of Tharwat Okasha, second edition, 1992, Egyptian General Book Organization, Cairo

16. Abu Nasr Ismail bin Hammad al-Jawhari al-Farabi (d. 393 AH), Taha Taj al-Luhah and Saheeh al'Arabiya, investigation by Ahmed Abdul Ghafoor Attar, edition: 1407 AH-1987, Dar al-Ilm for millions - Beirut 
17. Ahmed bin al-Qasim bin Khalifa bin Younis alKhazraji Muwafaq al-Din, Abu al-Abbas Ibn Abi Yogu'ah $(668 \mathrm{AH})$, the eyes of the news in the layers of doctors, the investigation of Dr. Nizar Reza, Library of Life - Beirut

18. Ahmad bin Ali bin Ahmed al-Fazari al-Qalqashandi and then al-Qahri (821 AH), Subh al-A'shi, in the construction industry, the scientific books house, Beirut

19. Ahmed bin Fares bin Zakaria al-Qazwini al-Razi, Abu al-Hussein (395 AH), the overall language, study and investigation Zuhair Abdul Mohsen Sultan, second edition - 1406 H - 1986, the Foundation letter - Beirut

20. Isma'il bin Muhammad Amin bin Mir-Saleem alBabani al-Baghdadi (1399 AH), a gift to those who know the names of the authors and the effects of the works, the House of Revival of Arab Heritage Beirut Lebanon

21. Statement and clarification, the Library and Library of the Crescent, Beirut, 1423 e

22. Tawfiq Brou, History of the Ancient Arabs, Second Edition, 1422 AH / 2001 AD, Dar al-Fikr.

23. Jarallah al-Zamakhshri (d. 583 AH), Rabie al-Abrar and the texts of the good people, first edition, $1412 \mathrm{AH}$, Al-Amali Foundation, Beirut

24. Jamal al-Din Abi al-Faraj Abdul Rahman Ibn alJawzi (508 AH / 597 AH), vaccination of the people of the impact in the eyes of history and walking, Dar alArqam ibn Abi al-Arqam, Beirut, 1997

25. The Population of Language, a symbolic investigation by Munir Baalbaki, first edition, 1987, Dar al-Ilm for millions - Beirut

26. Jawad Ali, detailed in the history of the Arabs before Islam, fourth edition, $1422 \mathrm{AH} / 2001$, Dar alSaqi

27. Georgy Zidane, The History of Islamic Urbanization, Cairo, 1958.

28. Hussain bin Ahmed bin Hussein al-Zuzni, Abu Abdullah (d. $486 \mathrm{AH}$ ), explanation of the seven pendants, first edition 1423 - 2002, the House of Arab Heritage Revival

29. Husayn ibn Muhammad ibn al-Hasan al-Dayyar Bakri (d. $966 \mathrm{AH}$ ), the date of Thursday in the circumstances of the souls of the souls, Dar Sader Beirut

30. Khairuddin bin Mahmoud bin Mohammed bin Ali bin Fares, Zarkali Damascene (1396 AH), the flags, edition: Fifteenth, 2002, Dar al-Ilm for millions

31. Dr. Emile Badi Yaqoub, The Detailed Dictionary in Shawad Al Arabiya, First Edition, 1417H - 1996

32. Reinhart Peter Ann Dozi (1300 AH), supplement of Arabic dictionaries, transferred to Arabic and commented by Mohammed Salim Al-Naimi, Jamal AlKhayyat, published by the Ministry of Culture and Information, Republic of Iraq, first edition, 1979-2000

33. The History of Islam and the Deaths of Celebrities and the Media, Omar Abdulsalam Al-Tadmari, Second Edition, 1413 AH-1993, Dar Al-Kitab Al-Arabi, Beirut

34. Shahabuddeen Abu Abdullah Yacout bin Abdullah Al-Roumi Al-Hamwi (626 AH), Dictionary of Literary Criticism, Ihsan Abbas, First Edition, 1414H-1993, Dar Al-Gharb Al-Islami, Beirut.

35. Abd al-Rahman ibn Nasr ibn Abdullah, Abu alNajeeb, Jalal al-Din al-Adawi al-Shazri al-Shafi'i (about $590 \mathrm{AH}$ ), the end of the rank in the request of the honorable Hesba,

36. Abdul Qader bin Omar al-Baghdadi, the treasury of literature and the core of the door of the tongue of the Arabs (1030/1093 e) investigation and explanation: Abdul Salam Mohammed Haroun, the fourth edition, 1418 e - 1997, Alkhanji Library, Cairo, 9/295

37. Omar bin Reda bin Mohammed Ragheb bin Abdul Ghani Kahala (d 1408 e), Dictionary of Authors, Muthanna Library - Beirut, Dar revival of Arab heritage, Beirut

38. Amr ibn Bahr bin Mahboob al-Kanani loyalty, Laithi, Abu Othman, famous Balaghz (d 255 e): animal, i 21424 e, the House of Scientific Books - Beirut 
39. Lapid bin Rabia bin Malik, Abu Aqeel al-Amiri poet numbered by the companions (d. 41 e), Diwan Labid bin Rabia al-Ameri, took care of: Hamdo Tamas, Dar al-Maarifa, first edition, 1425 e - 2004

40. Majd al-Din Abu Taher Mohammed bin Yacoub alFayrouzabadi (d. $817 \mathrm{AH}$ ), Dictionary surrounding, the investigation of the Office of Heritage investigation in the message, under the supervision of: Mohammed Naeem Erqsousi, the eighth edition, 1426 e - 2005, the message of the institution for printing, publishing and distribution, Beirut - Lebanon

41. Mohammed bin Ishaq Abu al-Faraj al-Nadim, Index, Dar al-Marefa, Beirut, 1398-1978

42. Muhammad ibn al-Hasan ibn Muhammad ibn Ali ibn Hamdun, Abu al-Ma'ali, Bahaa al-Din al-Baghdadi (d. 562 AH), Ticket Hamdouni, First Printing, 1417 AH, Dar Sader, Beirut

43. Mohammed bin Salam Al-Jamhi, layers of stallion poets, the realization of Mahmoud Mohammed Shaker, Dar Madani - Jeddah

44. Mohammed bin Abdul Qader al-Jazaeri, elite holding the horses in Alsafnat horses, I press National, Beirut, 1322 e

45. Mohammed bin Abdullah bin Abdullah bin Malik al-Ta'i al-Jiani (d. $672 \mathrm{AH}$ ), the completion of the media triangulation of speech, the achievement of Saad bin Hamdan al-Ghamdi, Mecca, 1404 e 1984

46. Mohammed bin Mohammed bin Ahmed bin Abi Zaid bin brothers, Qureshi, Ziauddin (d. 729 e), the features of the proximity in the request of Hisba, I Dar Arts

47. Mohammed bin Mohammed bin Abdul Razzaq alHusseini, Abu Fayd, nicknamed Murtaza, Zubaidi, crown of the bride of the jewels dictionary, the investigation of a group of investigators, I Dar guidance.

48. Mohammed bin Musa bin Issa bin Ali al-Dumairi, Abu al-Baqaa, Kamal al-Din al-Shafei (d. 808 e), the life of the great animal, second edition, 1424, Scientific Books House, Beirut
49. Mohammed bin Yusuf al-Salhi al-Shami (d. 942 e), ways of guidance and guidance, in the biography of the best servants, and mentioned the virtues and flags of his prophecy and deeds and conditions in principle and reconstituted, the investigation and suspension of Sheikh Adel Ahmed Abdel Mawjoud, Sheikh Ali Mohammed Moawad, the first edition 1414 e - 1993 , Scientific Books House Beirut - Lebanon

50. Mohamed Bayoumi Mehran, Studies in the History of Ancient Arabs, Second Edition, Dar Al-Marefah University.

51. Ad hoc, the achievement of Khalil Ibrahim Jaffal, first edition 1417 e 1996, Dar revival of Arab heritage Beirut

52. Mustafa bin Abdullah writer Chalabi Constantinian famous as Haji Khalifa or Haj Khalifa (d. 1067 e), revealed suspicions about the names of books and arts, Muthanna Library - Baghdad, 1941

53. Musab bin Mohammed (Abu Bakr) bin Masoud alKhashni Gianni Andalusian, Abu Dhar, (d. 604 AH), the short dictation in the explanation Ghareeb Sir, corrected Paul Brunel, Scientific Books House, Beirut Lebanon

54. Nashwan bin Saeed al-Humairi Yemeni (Tel: 573 e), Shams of science and the medicine of the words of Arabs Kalom, investigation: d. Hussein bin Abdullah al-Omari - Mutahhar bin Ali al-Iryani - d. Yousef Mohammed Abdullah, First Edition, 1420 H - 1999 AD, Dar Al Fikr Al Mu'asir (Beirut - Lebanon), Dar Al Fikr (Damascus - Syria) 